\title{
ОСОБЛИВОСТІ ЛЕКСИКО-СЕМАНТИЧНОЇ ОРГАНІЗАЦІЇ СИМВОЛІВ-ДЕНДРОНОМЕНІВ ДУБ І КАШТАН (на матеріалі української поезії кінця XX століття)
}

Колесникова Л. Л. Особливості лексико-семантичної організації символівдендрономенів дуб і каштан (на матеріалі української поезії кінця ХХ століття).

У статті розглянуто лексичне значення і семантичне розгалуження назв диких дерев, зокрема дуба і каштана, що репрезентовані в українських поетичних текстах кінця XX століття. Визначено характерні символічні особливості, архетипне походження й функціональна активність аналізованих номенів, доведено їхній зв'язок із традиціями і віруваннями українського народу.

Ключові слова: лексема, символи-дендрономени, символізація, семантичне значення, сема.

Колесникова Л. Л. Особенности лексико-семантической организации символовдендрономенов дуб и каштан (на материале украинской поэзии конца XX века).

В статье рассматривается лексическое значение и семантическое разветвление названий диких деревьев, в частности дуба и каштана, что представлены в украинских поэтических текстах конца XX века. Определяются характерные символические особенности, архетипное происхождения и функциональная активность анализируемых номенов, доказывается их связь с традициями и верованиями украинского народа.

○ Л. Л. Колесникова, 2015. 
Ключевые слова: лексема, символы-дендрономены, символика, семантическое значение, сема.

Kolesnikova L. L. Features of lexical-semantic organization of symbolsdendronomens oak and chestnut (based on Ukrainian poetry of the end of XX century).

The article deals with lexical meaning and semantic branching of names of wild trees, in particular oak and chestnut, which are represented in the Ukrainian poetic texts of the late twentieth. There are determined the characteristic of the symbolical features, archetypal origin and functional activity of the analyzed nomenaes, proved their relationship with the traditions and beliefs of the Ukrainian people.

Key words: lexeme, symbols-dendronomens, symbolism, semantic meaning, seme.

Стаття є продовженням низки публікацій, присвячених дослідженню мови українських поетичних текстів кінця ХХ століття.

Мета наукової розвідки - простежити трансформацію традиційних значень дендрономенів дуб і каштан у різних поетичних контекстах; виділити індивідуально-авторські значення та специфіку розгалуження семантичної структури аналізованих номенів 3 огляду на міфологічні витоки та культурно-історичні сфери буття.

У науковій літературі питанню антропоморфної інтерпретації, міфологізації та символічного значення назв дерев присвячені наукові студії О. М. Афанасьєва, М. І. Костомарова, О. О. Потебні, М. І. Гайковського, Д. В. Лісничого, І. В. Сабадоша, О. І. Сімович, О. С. Таран, Ф. Уїлрайта та інших.

Серед дендрономенів як носіїв різноманітних i своєрідних лексичних та семантичних відтінків вирізняємо дуб, який був священним деревом у багатьох народів: у кельтів, греків, римлян, слов'ян. Для розуміння символічних значень i розвитку семантики лексеми дуб необхідним $є$ аналіз міфологічного грунту взагалі та звичаїв і вірувань українського етносу зокрема.

Дуб вважали священним деревом Перуна, тому зрубувати його можна було лише 3 дозволу волхвів, котрі тлумачили шелест листя або воркування голубів на гіллі як знаки, що посилає дух дерева. Давні греки вважали дуб деревом Зевса, а римляни - Юпітера [8, с. 170]. У Дамаску, наприклад, зберігся Храм Ваала, побудований у дубовому гаї. Дубу була властива велика святість: у скептика, який відрубував хоч би одну гілку, відсихала рука. Спрадавна дуб становив божественну тріаду. За ізраїльськими народними уявленнями, Бог i Його ангели постали у вигляді трьох чоловіків, які скуштували іжу, 
запропоновану хазяїном під тінню священного Мамврійського дуба, що стояв там «від заснування світу». Дуб був і атрибутом царської влади: у Біблії згадано «царський дуб», що розмежовував землі й під яким «благословляли на престол» [1 Суддів 9:6].

Шанобливе й поважне ставлення до дуба, що бере початок від стародавніх вірувань, спостерігаємо й зараз: у багатьох місцевостях України дуб - привілейоване дерево. Дендрономен дуб є своєрідним синонімом дерева взагалі, деревом предків, найпоширенішим утіленням ідеї світового дерева.

У замовляннях дуб - не рослина, а, швидше, місце; символ радше «топографічний», ніж ботанічний. Він - середина зеленого царства або концентричної моделі світобудови [6, с. 234], тому існує версія, що в основі символізації дендрономена дуб збережено архетип світова вісь.

Багатство семантичної структури символічної одиниці дуб зумовлено й давнім походженням аналізованої лексеми, яка спочатку мала значення «будь-яке дерево», «дерево взагалі», тобто «ліс». Це слово передавало значення «чогось цілісного, що не роздроблюється на частини..., чуже, нескорене, якому, між іншим, «слід приносити жертву», тобто дуб символізував щось монолітне, безмежне, сильне [8].

Традиційна архетипова сема 'сила' пов'язує дендрономен дуб 3 уявленням про фізичну силу й міцну статуру: укр. здоровий (міцний статурою, сильний) від псл. *sъdorvъ, що складається 3 двох формантів: sъ-, спорідненого з д.-інд. «добрий», i *dorvo-, пов'язаного чергуванням 3 дерево, тобто буквально «з доброго дерева» [7, т. II, c. 90].

Семантика лексеми-символу дуб залежить від іiі прямого номінативного значенням, зафіксованого сучасною українською мовою. Дуб - «1. Багаторічне листяне дерево 3 міцною деревиною та плодами - жолудями. 2. діал. Великий човен, видовбаний з суцільного дерева (перев. дуба) або зроблений з дощок. 3. техн., розм. Речовина, що використовується для вичинки шкіри» [5, т. II, с. 428].

В українській системі символів дуб - символ дерева життя; гордості й міці, сили, довговічності, здоров'я, цілісності; дужого, гарного парубка; нерозважливості. У фольклорі дуб - символ чоловіка в різних видах життя; а сухий дуб - нещасний чоловік, який переносить своє горе за допомогою міці духу [3].

ㄷ Л. Л. Колесникова, 2015. 
Поетичний твір кінця XX ст. спирається на символ-дендрономен дуб як на стійкий елемент культурного континууму й, разом 3 тим, розширює його семантичне коло: Із країв, де суворі спеки, / Довгождані, жадані, любі, / Прилетіли в село лелеки, / Ремонтують гніздо на дубі. / Носять в парі сухенькі віти, / Чути клекітну їхню мову. / Хе! Тепер защебечуть діти / І в оселях села. Чудово! (5, с. 50).

Дуб - значуща символічна одиниця, що має значення «місце, на якому знаходиться пташине гніздо». На перший погляд, аналізований дендрономен ужито в його прямому номінативному значенні. Наявність інших традиційних символів (лелеки, гніздо) зумовлює семантику й конотативні відтінки символу дуб. Дуб - не просто рослина, він - дерево життя, що містить не лише основні семи 'міць, сила', а й активізує периферійні - 'цілісність', 'центр'. Двочленна будова тексту дозволяє виділити символічні пари лелека - дуб і діти оселя, які трансформуються в асоціативні вертикальні паралелі лелека - діти, дуб - оселя на тій підставі, що символічні одиниці лелека й дуб належать до вищого рівня, а діти й оселя - до нижчого.

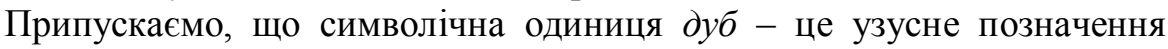
оселі вищого рівня зі збереженням первинної семи 'сила', 'міць', що входить до лексико-семантичної групи «захист». Семантичний перехід дерево $\rightarrow$ здоровий, сильний, як зауважує Г. М. Яворська, $є$ прикладом семантичного розвитку від конкретного до абстрактного, від конкретного предметного значення до позначення абстрактних понять здоров'я й фізичної сили [9, с. 67].

«Децентралізація» основної семи 'сила, міць' відбувається в разі вживання із символом-дендрономеном дуб атрибутивного компонента старий, напр.: Багрянцем захід вишивав отаву, / Старого дуба сон уже зборов. / Одного дня закінчилась вистава, / Вистава інша завтра буде знов $(6$, с. 7$)$.

У словосполученні старого дуба виділяється центральна сема 'вік', що розкладається на міні-семи 'нікчемність', 'пригніченість'. Останні виділяються через метафору «сон уже зборов». Загальна парадигма дерево - людина звужується до контекстуальної дуб старик. Антропоморфний фон є додатковим у створенні нетрадиційної рольової картини буття: усе позначуване лексемою життя вкладається в одне слово - вистава. У зв'язку 3 цим з'являється асоціативна парадигма вистава - життя, яку суб'єктивно називаємо горизонталлю 
і яка завдяки антропоморфізму утворює пари вистава - дуб (у значенні образу) і життя - людина. Такий поділ, звичайно, є лише контекстуальним і наділений деяким рівнем домислу та асоціацій.

Номен дуб у тексті зазнає депоетизації, спостерігаємо зниження рівня образності й позитивного оцінного компонента: Вичікує літо / прощення й відліту, / збирає на силі, шикує ряди. / До першої опали / відважно ступали, / наступні колишні дарують сліди. / Для нас із тобою / вродили набої, / в дубів - патронташі точених плодів (4, с. 37).

Символічна одиниця дуб входить до тематичної групи літо, але опосередковано. Поетичний твір із субстантивами літо, дуби не має навіть натяку на пейзаж. Метафорична палітра тексту «епатажована» лексемами військової тематики: шикує ряди, відважно, набої, naтронташі. Структура поетичного тексту представляє «семиантагоністи»: 'захист' - 'напад'. Лексема дуб контекстуально є своєрідним «вмістилищем зброї», що асоціюється 3 дубовими плодами, отже, виникає парадигма жолудь - зброя.

Від лексеми дуб утворено похідний прикметник дубовий, який також може мати символічне значення. Словосполучення дубовий гай частково або повністю зберігає семантику дендрономена-символу дуб i водночас набуває похідної семантики шляхом поєднання із символічним значенням лексеми гай: Нa садибi Тобілевичів / nid Кіровоградом - / дубовий гай. / У кожного дерева є ім'я. / Дерево дід. / Дерево батько. / Дерево син. / Посади своє дерево / в иім / вічнозеленім гаю! (2, с. 139).

Просторова ботанічна одиниця гай, окрім прямого номінативного значенням, має символічне: гай - символ землі; місце небезпеки, мешкання духів [8, с. 280]. У поетичному тексті гай не лише місце, наділене негативною конотацією, а, навпаки, священний оберіг людини. Мотив поетичного дубового гаю переплітається 3 думкою про колишнє існування під Києвом священного дубового гаю (про що свідчать нинішні старовинні дерева й давні назви навколишніх сіл Вища й Нижча Дубечня). Безпосередню назву дуб у структурі тексту заміщає лексема дерево (архетип світова вісь), яка входить до конкретизованих парадигм дерево - дід, дерево - батько, дерево син. Останні виокремлюємо в узагальнену парадигму дерево - чоловік, отже, - дуб - чоловік, що грунтується на спільній семі 'міць'. Атрибутивна словосполука вічнозелений гай репрезентує вторинні 
семи, наявні в складному прикметнику вічнозелений: ‘життєдайність', 'безсмертя'.

Припускаємо, що вічнозелений дубовий гай має значення продовження роду, підтвердженням чого $є$ поетичний компонент «оосади своє дерево».

У віршованих текстах фіксуємо символи-дендрономени, що не мають значної функціональної активності. Це пов'язано передовсім 3 роллю й місцем ботанічної одиниці в конкретній місцевості та ставленням до неї народу. До цієї групи належать, зокрема, символічна одиниця каштан.

Лексема каштан позначає дерево «з видовжено-ланцетними листками й спрямованими догори суцвіттями» і плодом брунатного кольору, що має форму горіха [5, т. IV, с. 126]. Етимологія аналізованої лексеми доволі складна. Каштан - рос., блр. каштан, чес. kaštan, пол. kasztan, слц. gaštan; через польське й чеське посередництво запозичене з німецької мови (каstanie), у яку, імовірно, прийшло 3 мов Малої Азії: пор. вірм. kask «каштан», kaskeni «каштанове дерево»; болг. кестен, схв. кесте̄н [2, т. II, с. 411].

У системі символів дендрономен каштан $є$ порівняно новою одиницею. Осмислення його як символу відбувається лише контекстуально й пов'язане 3 узуальним функціонуванням лексеми каштан. Аналізований дендрономен користується значною повагою серед киян, навіть можна припустити, що каштан - «осучаснене» культове дерево. Поетичний текст містить співвіднесення каштани країна й може мати негативний оцінний компонент i відчуття трагізму, напр.: 3 тріском летять голівки / Страчених антуанеток - / То опадають каштани, / То опадає краӥна (1, с. 56). Предикативна сполука, що містить дієслово опадають, пов'язана 3 «нижнім» рівнем символізації (опадати - «рухатися вниз, до землі»). Саме дієсловоприсудок впливає на семантику лексеми каштани, і це репрезентує спільну сему 'втрата'. Дієслівна форма опадає поєднується 3 іменником країна, зберігаючи свою семантику. Це дає підстави для виділення паралелі каштани - країна, в основу якої покладено не спільну сему лексем каштани та краӥна, а вторинну (похідну), репрезентовану символічно значеннєвим компонентом опадати.

Лексема каштан входить і до визначення просторового місця подій, конкретизація якого відбувається лексичним оточенням 
дендрономена каштан, напр.: Де каштан небеса підпер, / Де навіки заснуло місто, / Я долонями очі тер - / Назвіть мене терористом. / Я за щуось довіряв сльозам. / Я блукав ичим шаленим краєм / Був я дикий $i$ був я Сам - / Назовіть мене самураєм / Ще побачу $i$ те, $і$ се. / Ще проїдусь в купе двоміснім. / А для мене реально все - / Назовіть мене реалістом $(7$, с. 76$)$.

Основна сема 'сила', зумовлена зовнішнім виглядом ботанічної одиниці, трансформувалася в другорядну (похідну). Тобто явище перерозподілу сем презентує лексему каштан як символічно вагомий компонент, що має значення місце. Деякого рівня абстракції досягнуто повною відсутністю конкретизації лексем місто і край. Семантична структура тексту виокремлює сему 'сум' через наявність у поезії емоційно й значеннєво зниженої лексики на зразок навіки заснуло, терорист, шалений край, дикий, блукав.

Видова номінація каштан входить до мікрообразів зі значенням місие й час, що розкриваються через концепт назви твору - «Будинок інвалідів». Негативний емоційний характер, що міститься в назві, згущено й контекстуальними пейзажними елементами 3 різноступеневим психологічним емотивом: Будинок інвалідів / Надвечір'я. Каштани. / Дім (і погляд «Побудь!»), / Де не гояться рани, / Де чекання живуть. / Обминути - жорстоко. / Сутеніє. Паркан! / Повз хвилини, повз роки / Ронить листя каштан.» (3, с. 13). Плин часу у віршованому тексті виражено дієсловом сутеніє, він досягає апогею в останніх рядках. Семантична трансформація лексеми каштан потрапляє в семантичний комплекс життя минає, що презентовано прийменниковими конструкціями повз хвилини й повз роки. Поєднуючись із дієсловом-присудком ронить, субстантив каштан активізує похідну сему 'втрата', централізовану в семантичній структурі життя минає, і концептує сему 'смерть'.

Як свідчить аналіз фактичного матеріалу, у поетичному творі спостерігаємо низький рівень символізації дендрономена каштан. Це зумовлено, імовірно, тим, що аналізований номен не належить до системи традиційних символів. На семантичну структуру лексичної одиниці впливають дієслова-присудки, за допомогою яких i відбувається перерозподіл сем. Так, лексема каштан активізує контекстуальну сему 'втрата', яка $\epsilon$ центральною в паралелі каштани - краӥна і в синтаксемі життя минає.

๑ Л. Л. Колесникова, 2015. 
Отже, у зв'язку з тим, що дендрономену каштан не властива символічна багатоплановість, зараховуємо його до розряду символічно значущих елементів. Відповідно символ-дендрономен дуб у поетичному тексті має складну, доволі суперечливу лексикосемантичну структуру. Це зумовлено індивідуальним баченням i визначенням ролі аналізованої символічної одиниці; збереженням / утратою міфологічних витоків і відповідної традиційної семантики, пов'язаної з фізичною силою.

\section{Література} $1255 \mathrm{c}$.

1. Біблія, або Книги Святого Письма Старого й Нового Заповіту. - Б. м., 1990. -

2. Етимологічний словник української мови : в 7-и т. / АН Української РСР. Ін-т мовознавства ім. О. О. Потебні. - К. : Наукова думка, 1982 - 2012. - Т. 1. А-Г. - 1982. -631 с. ; Т. 2. Д-Копці. $-1985 .-569$ с.

3. Костомаров М. І. Слов'янська міфологія : вибр. пр. 3 фольклористики й літературознавства / М. І. Костомаров. - К. : Либідь, 1994. - 384 с.

4. Словник символів / О. І. Потапенко, М. К. Дмитренко, Г. І. Потапенко та ін. К : Ред. часоп. «Народознавство», 1997. - $156 \mathrm{c}$.

5. Словник української мови : в 11-и т. - К. : Наукова думка, 1970-1980. - Т. 1-11.

6. Українські замовляння / упоряд. Н. М. Москаленко ; авт. передм. М. О. Новикова. - К. : Дніпро, 1993. - 309 с.

7. Фасмер М. Этимологический словарь русского языка : в 4-х т. / М. Фасмер. М. : Прогресс, 1964-1973. - Т. 1-4.

8. Энциклопедия символов, знаков, эмблем / авт.-сост. В. Андреева и др. - М. : ООО «Издательство Астрель» : МИФ : ООО «Издательство АСТ», 2001. - 576 с.

9. Яворская Г. М. Лексико-семантическая типология в синхронии и диахронии / Г. М. Яворская. - К. : Наукова думка, 1992. - 110 с.

\section{Список використаних джерел}

1. Балдинюк В. Крамничка вживаних речей : вірші / В. Балдинюк. - К. : Смолоскип, 1999. - 68 с.

2. Біливода П. Ось така мені випала доля : поезії та листи / П. Біливода. - К. : Молодь, 1998. - $224 \mathrm{c.}$

3. Литвинчук Л. Вірші / Л. Литвинчук // Прапор. - 1988. - № 7. - С. 13.

4. Розумний М. Рамаян : поезії / М. Розумний. - К. : Смолоскип, 1997. -87 с.

5. Савич I. Партитура тривоги : поезії / І. Савич. - Луганськ : Спілка журналістів України, 1994. $-88 \mathrm{c}$.

6. Світличний I. На березі вічності : поезії / I. Світличний ; ред.-упоряд. Л. П. Стрельник. - Луганськ : Спілка журналістів України, 1994. - 80 с.

7. Скиба Р. Хвороба росту : поезії / Р. Скиба; післямова І. Старовойт. - К. : Смолоскип, 1998. - 240 с.

Стаття надійшла до редакиії 22.03.2015 p. 